tends to make food go bad more quickly when it is re-exposed to the ordinary temperature. Cold does not improve articles already commencing to decompose; but, on the other hand, if scientifically carried out-that is, if the food is in excellent condition to begin with, and is preserved with all due precautions as regards the correct temperature, its uniform maintenance, and the proper hygrometric condition and frequent renewal of the air in the store-room, and if the lowering and raising of the temperature do not take place too suddenly-no harmful consequences follow refrigeration.

F. SODdy.

\section{THE NATURAL HISTORY OF A LONDON SUBURB.'}

THE increasing demand for worles on local natural history, of which class of publication the present volume is an excellent specimen, must have been noted by workers in science as a healthy sign of popular awakening. But while in the eighteenth century it was possible for a Gilbert White to cover the whole ground so far as concerned his own district, the great development of specialised knowledge in modern times necessitates the cooperation of many workers to produce such a volume as that under consideration. Thus, in addition to the opening chapter on: topography, by Messrs. Maynard and Findon (the hon. sec. of the natural history section of the society), there are ten chapters by different authors dealing respectively with the geology, climate, plant-life (three chapters), bird-life, mammals, \&c., insects, molluscs, and pond-life together with a very useful bibliographical appendix.

A commendable feature of the present work is the general introductory section heading many of the chapters. By this treatment the reader is enabled to pass from the general to the special-a method which may be condemned by some critics as an inversion of scientific method but, in a local natural history, has the distinct advantage of enabling the general reader and the would-be student to realise that the local and restricted data supplied by his own district fit in to the larger and more comprehensive generalisations which scientific observers have built up from detailed observations over wider fields. The chapter by Mr. A. G. Tansley dealing with the vegetation (chap. iv.) is a very good example of the treatment referred to, as he begins with the ecology,

1 "Hampstead Heath: Its Geology and Natural History." Prepared under the Auspices of the Hampstead Scientific Society. Pp. $328+x i$ plates + 3 maps. (London; T. Fisher Unwin, n.d.) Price ros. $6 d$. net.

NO. 2292, VOL. 92] shows the relationship of the vegetation to the geological features, and then groups vegetation generally under the various types of "associations " before dealing with the particular plantassociations of the district. The lists of species then come as natural sequences to the various "associations." A living interest is thus imparted to a subject which in former times was presented

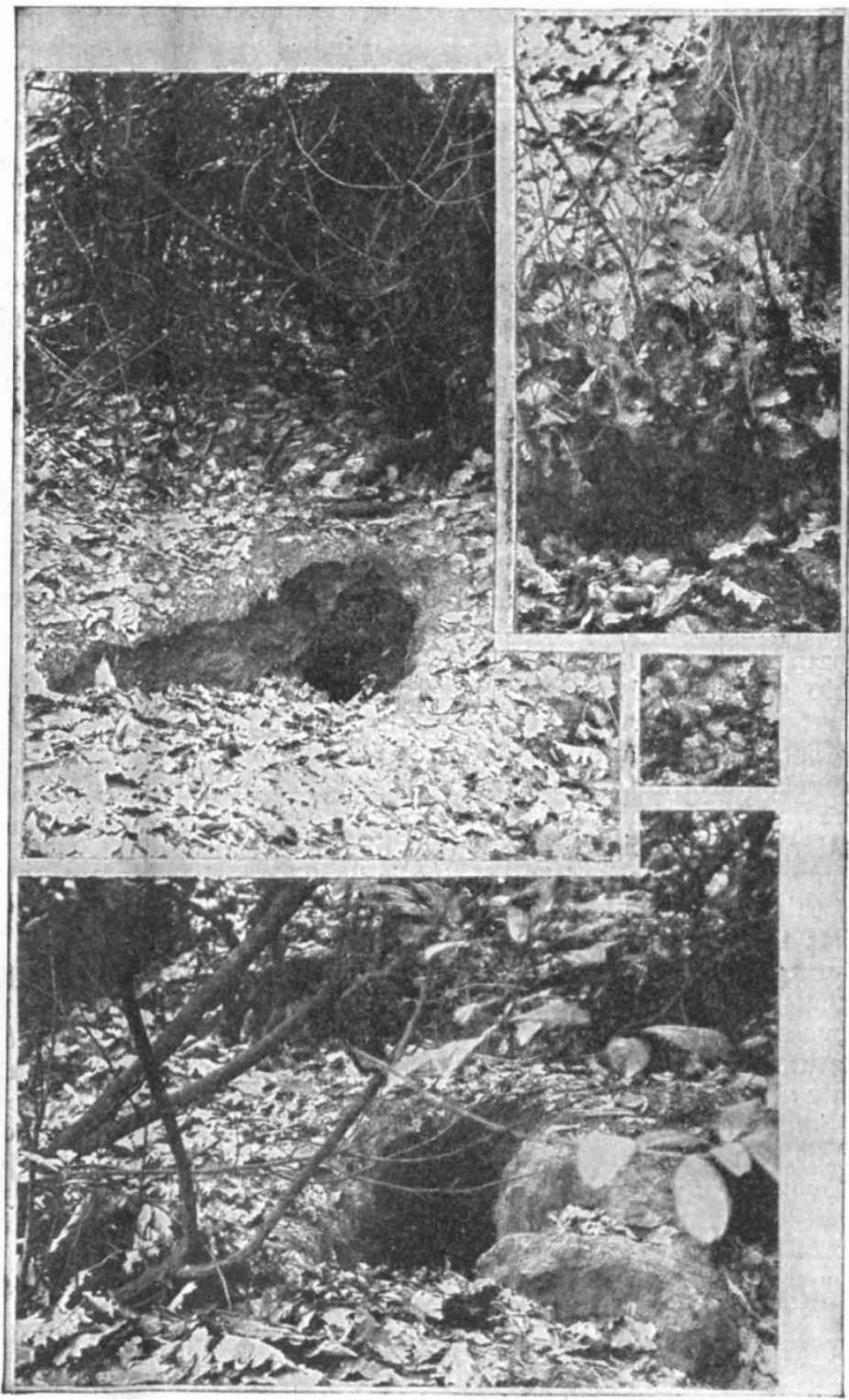

Badger Earths in Ken Wood. From " Hampstend Heath : Its Geology and Natural History."

in the uninteresting form of a catalogue of names, amounting, in fact, to nothing more than the statement of the occurrence of a certain species in a particular district, without any relationship to its environment or to its associates. The chapter on the trees and shrubs (chapter v.), by Mr. Hugh Boyd Watt, will surprise many readers as a revelation of the extreme richness of the district, all 
the native English trees, and also a large number of foreign species, finding the conditions suitable for their growth. How long these conditions will remain favourable is problematical, a remark which applies also to Mr. Whitton's goodly list of some 300 species of flowering plants given in chapter vi.

The geology of the district is necessarily " tame," but since Mr. F. W. Rudler is responsible for that chapter (chap. ii.), it is perhaps scarcely necessary to say that it will be found both interesting and instructive. The only regret is that the author did not "let himself go" more freely in discussing some of the generalisations which have of late years been based upon the detailed study of gravels and superficial deposits generally. In connection with the climate of Hampstead (chap. iii., by Mr. E. L. Hawke), it is of interest to note that the sunshine record, as compared with that of the city, more nearly approaches that of Berkhamstead, which is tolerably clear of London influence. Thus the total number of hours of bright sunshine during I9ro was I372, as compared with I 348 at the Hertfordshire station, I 83 at Camden Square, and 993 at Bunhill Row. So much for the effects of atmospheric pollution in the City of London! Bird-life (chap. vii.) is dealt with by Mr. Herbert Goodchild, who gives a very clear account of the particular conditions favourable and unfavourable to an avifauna. One of his observations is very significant: "Adjoining the heath are several private woods, a form of ownership which tends to the preservation of species that might otherwise be lost to the district, since in such woods and coppices the birds are safer from molestation. As some of these woods adjoin the public domain, an observer may see on the latter many species of birds that might be driven away if all the woods were public." The writer of this notice has long ago come to the conclusion that the preservation of open spaces solely from the point of view of the "recreation and enjoyment of the public" is in many cases quite the reverse of a boon from the point of view of the naturalist. Mr. Goodchild is, of course, an advocate of the study of bird-life by the modern method -i.e. the field-glass and camera, and not by the gun. It is fortunate for the district, also, that it comprises the Brent reservoir, and that that well-known observer Mr. J. E. Harting was a former resident, and kept observations of the birds for many years.

The chapter on mammals, fishes, and reptiles, by $\mathrm{Mr}$. Hugh Findon, will also surprise many readers who are unprepared for the survival of such a number of species within sight of the metropolis. The existence of badger-earths, still apparently tenanted, is certainly remarkable, but here, again, the preservation of this notoriously shy animal is due to the inclusion of the earths (a figure of which we reproduce) in the private grounds of Ken Wood, the owner of which estate has always been a sympathetic conservator of this interesting denizen. Dr. O'Brien Ellison's chapter on insect-life serves to emphasise the complaint so frequently made by entomologists in this country that local collectors so generally concentrate their attentions upon the Lepidoptera to the neglect of other orders. There are surely more than twenty-seven species of Coleoptera in the district, to say nothing of Hymenoptera, Diptera, and Microlepidoptera. The list of Lepidoptera, by the way, is marred by a number of misprints. It only remains to add that there are chapters on molluscs and on pond-life by Mr. Hugh Findon and Mr. James Burton respectively.

The Hampstead Scientific Society has certainly done good service in publishing this volume, which is a typical specimen of the kind of work which local societies should undertake. For a district such as that dealt with-viz. within the threemile radius from the flagstaff on the summit of the heath-a book like that before us is not only of immediate utility, but is certain to acquire increased value as time moves on and the influence of urbanisation becomes more and more pronounced. Already many of the species recorded are taken from old publications, and are now extinct. The general impression produced by the perusal of the volume is one of marvel at the persistence of so much that is "natural" in the area described.

R. M.

\section{PROF. HUGH MARSHALL, F.R.S.}

$\mathrm{BY}$ the untimely death of Prof. Hugh Marshall, which took place in London on September 5, chemistry has lost, at the early age of forty-five, one of the nowadays comparatively few prominent men who devoted their energies to the investigation of subjects connected with the inorganic and mineralogical branches of the science, and the University of St. Andrews an active and useful member of the professorial staff of Dundee University College.

It is not a disparagement to say that Dr. Marshall's mo'st brilliant discovery-that of the persulphates, in $189 \mathrm{I}$ - was due to one of those fortunate chances, not infrequent in science, where experiments designed to elucidate a certain definite question lead to some new discovery of a wholly different description and often of much greater consequence; for, no sooner was the discovery made than its author was quick to discern that substances of far-reaching importance had fortuitously presented themselves to him and to prosecute their examination with exceptional vigour and success. The subject under immediate investigation was the oxidation of cobalt salts by electrolysis in the then comparatively little employed "divided" electrolytic cell, and on passino a current of electricity through " a fairly acid solution of cobalt and potassium sulphates," with a view to prepare potassium cobalt alum, small crystals slowly separated, which proved on analysis to consist of potassium persulphate. The discovery of the persulphates at once brought Dr. Marshall's name into prominence, while the assiduity and skill with which he continued his examination of them speedily marked him as a rising inorganic chemist. 